S. V. Ladokhin, Dr. Sci., Chief. Researcher.

M. M. Voron, Ph.D., Senior Research Scientist, mihail.voron@gmail.com

Ye. O. Drozd, Junior Researcher

Ye. O. Matviets, Chief Technologist

${ }^{*}$ L. D. Kulak, Ph.D., Senior Research Scientist

* M. M. Kuz'menko, Ph.D., Senior Research Scientist

Physical-Technological Institute of Metals and Alloys of the NAS of Ukraine * Institute for Problems of Materials Science named by I. M. Frantsevich of the NAS of Ukraine

\title{
FEATURES OF OBTAINING TITANIUM ALLOYS OF Ti-Al-Si-Zr-Mo-Nb-Sn SYSTEM UNDER CONDITIONS OF ELECTRON-BEAM FOUNDRY TECHNOLOGY
}

The article is devoted to the problem of obtaining a heat-resistant complex alloyed titanium alloy of Ti-Al-Si-Zr system additionally alloyed with Molibdanium, Niobium and Stannum under the conditions of electron-beam foundry technology. On the basis of current trends in the development of heat-resistant titanium alloys, an analysis of compositions development for operating at temperatures of $600{ }^{\circ} \mathrm{C}$ and potentially capable for operating at temperatures up to $700{ }^{\circ} \mathrm{C}$ has been performed. It is concluded that the well-known commercial alloys, which are implement the mechanism of solution hardening, as well as alloys based on intermetallic have a number of disadvantages and do not fully meet the current requirements for this class of materials. It is shown that the development and creation of titanium alloys, which can combine the mechanisms of solution and silicidal hardening is the most promising solution for a significant increase of their high temperature characteristics. One example of such a group of alloys is the composition Ti-7Al-1Si$4 Z r-1 M o-1 \mathrm{Nb}-1 \mathrm{Sn}$, developed at IPM NAS of Ukraine. Such an alloy is not too costly and somewhat lighter than its existing counterparts. The production of finished and semi-finished from such alloys is usually carried out by casting methods or by metallurgical electron-beam melting technology. From the view point of such alloys experimental nature, there is a need to study the technological features of smelting such material, determine the behavior of components in the melting process and melt preparation, obtain high-quality workpieces for further thermomechanical processing and research. To solve these problems, the most appropriate is the use of electron-beam foundry technology. In the course of the experimental alloy smelting experiments, melt preparation of the required chemical composition technological features were identified, among which the main ones were the procedure for aluminum addition and the mixing of elements with high density.

Keywords: heat resistant titanium alloys, $\mathrm{Ti}-\mathrm{Al}-\mathrm{Si}-\mathrm{Zr}-\mathrm{Mo}-\mathrm{Nb}-\mathrm{Sn}$ system, electron-beam foundry technology, casting of titanium and its alloys.

T itanium alloys are one of the most promising materials of our time due to the combination of high specific strength, ductility, corrosion resistance and the possibility of varying these characteristics over a wide range both by alloying, deformation, heat treatment and their combination [1, 2]. These materials have a wide field of application and are characterized by a large number of existing chemical compositions. In general, titanium alloys are divided into 5 groups - three basic (by phase composition) and two conditional. The main ones include $\alpha-, \alpha+\beta$-, and $\beta$-titanium alloys, and conditional ones include eutectic alloys and intermetallic-based alloys [2].

Compared to nickel-based superalloys, most titanium alloys are inferior in their ability to withstand loads at high temperatures. Nickel-based alloys, despite the low melting point $\left(1455^{\circ} \mathrm{C}\right)$, can be used at operating temperatures of $900-1000^{\circ} \mathrm{C}$. Relatively low heat resistance of titanium alloys is primarily caused by the low Young's modulus ( $112 \mathrm{GPa}$ for pure titanium) and the presence of polymorphic transformayion at $882^{\circ} \mathrm{C}$ (near this tem- 
perature, the elasticity and strength characteristics are dramatically reduced). Most of the heat-resistant titanium alloys developed have operating temperatures not higher than 600 ${ }^{\circ} \mathrm{C}$ [3]. Therefore, the urgent issue in the field of modern development of titanium alloys is the development of new heat-resistant compositions that are able to work effectively at temperatures of about $700^{\circ} \mathrm{C}[4,5]$.

The principles of titanium alloys with high heat resistance creation are based on the material structural-phase characteristics and the mechanisms of their formation and existence. The possibilities of solid solution hardening are largely exhausted, though one can note the brilliant development of materials such as IMI-834, TIMETALL-1100 and others. (USA), BT-18, BT-23 (USSR). The working temperature of such alloys is limited to $600^{\circ} \mathrm{C}$. A number of materials additionally alloyed with $\mathrm{V}, \mathrm{Cr}, \mathrm{Mn}, \mathrm{Nb}, \mathrm{W}$ and the so-called $\mathrm{XD}$-TiAl with boride hardening were created on the basis of titanium $\gamma$-aluminides. These materials significantly outperform the finest metallic materials in specific heat resistance and elastic modules over a wide temperature range (up to $600^{\circ} \mathrm{C}$ ) and exhibit high heat resistance and fire resistance. The research and development of these materials is ongoing in the United States (Howmet), Germany (Daimler Benz, Eisenforschung GmbH, Motorenund Turbinen Union, Deutsche Titan $\mathrm{GmbH}$ ), Japan (NRIM), Russia (VIAM, Prometheus). However, despite the aforementioned advantages, limited plasticity and brittleness at normal temperatures hinder their practical use. $\mathrm{Ti}_{3} \mathrm{Al}$-based intermetallic materials, additionally alloyed with a significant amount of niobium ( 20\%), especially $\mathrm{Ti}_{2} \mathrm{NbAl}$-based alloys, have a relatively high specific weight, low Young's modulus and strength. The price of such alloys remains relatively high $[4,6,7]$.

Due to such facts, the materials with two strengthening mechanisms connection - solid soluble and dispersive due to the formation of silicides seem to be more attractive [8-10]. Titanium alloys in which silicidal hardening is realized have non-deficient components in their composition, and their value is about level of commercial alloys.

Some of these alloys require improved processability, low temperature ductility and optimization of chemical composition to work at elevated temperatures. So it is important to understand the complex alloying of the alloys and the mutual effective operation of their components. For example, aluminum and silicon are the main elements that provide creep resistance and heat resistance of an Ti-based alloys. Some refractory elements such as $\mathrm{W}, \mathrm{Mo}, \mathrm{Nb}$ and some others can stabilize these properties sdditionaly. Zirconium and tin, which are isomorphic titanium strengthening elements, have a positive effect on the strength and are able to increase alloys ductility [1, 2, 11-13]. According to this principles, $\mathrm{Ti}-\mathrm{Al}-\mathrm{Sn}-\mathrm{Zr}-\mathrm{Mo}-\mathrm{Nb}-\mathrm{W}-\mathrm{Si}$ alloys have been created in recent years, and seemed to be capable of operating at temperatures above $600^{\circ} \mathrm{C}$. They are characterized by a low content of aluminum and silicon. Examples of such compositions are Ti-6,5Al-2Sn-4Zr$1 \mathrm{Mo}-3 \mathrm{Nb}-0,5 \mathrm{~W}-0,2 \mathrm{Si}$ and $6,2 \mathrm{Al}-3 \mathrm{Sn}-3 \mathrm{Zr}-1,5 \mathrm{Mo}-1,5 \mathrm{Nb}-0,5 \mathrm{~W}-0,15 \mathrm{Si}[14,15]$.

At the I.M. Frantsevich Institute for Problems of Materials Science NAS of Ukraine similar systems alloys are being developed. The Ti-Al-Si-Zr-Mo-Nb-Sn alloy is devoid of tungsten for a number of reasons. The high density of this element and the technological complexity of its addition increases the cost of obtaining a high-quality finished nd semifinished products, which are usually obtained by casting methods.

One of the most promising casting method for the production of such type titanium alloys is electron-beam foundry (or casting) technology (EBCT), developed at the PhysicalTechnological Institute of Metals and Alloys NAS of Ukraine. This method is the closest derivative of the basic industrial technology for smelting of this type of materials - electron beam melting process.

EBCT is a method in which an electron beam generated by an electronic gun acts as an independent source of heating. The electron beam heats the metal, deposited in a copper water-cooled crucible equipped with an electromagnetic melt stirring system. The electromagnetic stirring (EMS) ensures the movement of the metal in the crucible, resulting in heat exchange processes, homogenizing the chemical composition and forming the required melt volume. Also, metal charge can be used both in the form of a 


\section{Одержання та обробка розплавів}

consumable electrode billet, and in the form of a lumpy charge (chips, sponges, waste). The disadvantages of the technology include the loss of metal at the level of $1-7 \%$, depending on the component and its content. In this regard, the overall complexity of obtaining multicomponent alloys of the exact chemical composition process is noted. However, this technology is by far one of the most effective ways of producing high quality titanium castings [16].

In [17-19], the efficiency of using electron beam technology to produce a variety of cast products using a wide range of titanium alloys is proved. First of all, the purity of the metal, product defect and structural-phase characteristics are noted. Examples of castings obtained by this method are shown in the figure.

The research objective was to obtain a cast billet from an alloy of the following chemical composition: (7-8)Al-(3-4) Zr-(0,9-1,1)Si-(0,7-1)Mo-(0,8-1,2) Nb-(2-3)Sn (\%, wt.). For the smelting process, a skull of technically Grade2 pure titanium was selected. Technically pure Grade2 titanium and $\mathrm{Zr}-1 \mathrm{Nb}$ alloy were used as a lumpy charge. Pure silicon in the form of scales, molybdenum and niobium in the form of staples and tin in form of granules were also used.

The order of insertion and placement of the charge inside the crucible is very important for the smelting of heavily alloyed titanium alloys containing significant amounts of aluminum and high density components at the same time. Thus, titanium and zirconium were charged in crucible, and refractory components such as niobium and molybdenum were placed on top. It was decided to inject aluminum, silicon and tin under the electron beam focus area and to fuse it into the metal bath at the end of the melting process to reduce their evaporation time and to reduce the loss of components, especially aluminum.
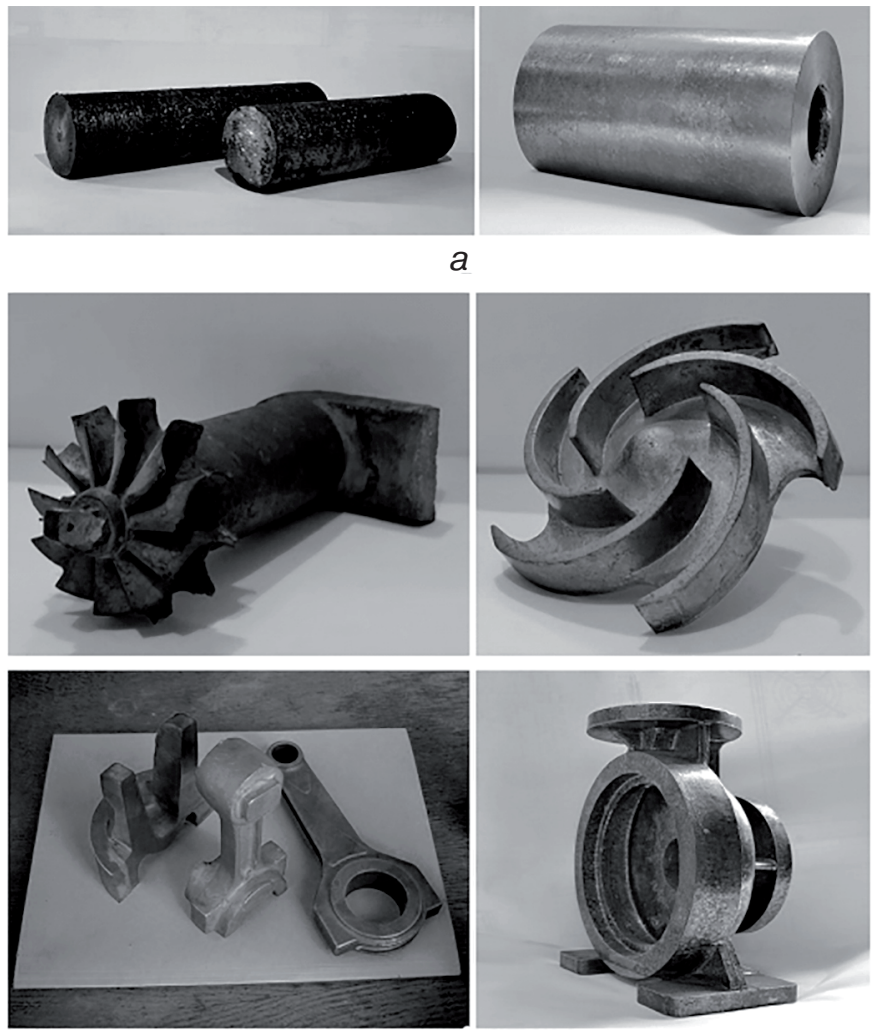

$b$

Figure. Examples of cast titanium semi-finished products appearance $(a)$ and cast products $(b)$ obtained under EBCT conditions 
During the melt preparation, a slight melting of the skull side walls was performed first to cover its bottom. This technique serves as a benchmark for determining the volume of a liquid metal bath at the end of the melting process. The deposited metal layer after blurring opens the bottom of the skull, which is usually the most oxidized. Thus, a slight decrease of the vacuum in the final stages of melting indicates that at present the melt volume corresponds to a volume of charged charge. The vacuum returns almost immediately to its previous values.

Further there is a simultaneous gradual fusion of titanium and zirconium with refractory components. The melt of titanium and zirconium is quite homogeneous, and the mixing of small portions of refractory components significantly increases the degree of their absorption and ensures their even distribution in the volume of the liquid metal bath. Addition of a liquid charge with high partial pressure components state is useful to provide in the end of the process to reduce their evaporation.

The smelting of the experimental alloy was based on the above principles for the first experiment. Further process analysis is contributed to changing the algorithm of work. The table below shows the results of three experimental smelting processes.

\section{Chemical composition of charge and obtained ingots (wt. \%), Ti-balance}

\begin{tabular}{|c|c|c|c|c|c|c|c|}
\hline \multirow{2}{*}{ Element } & \multicolumn{2}{|c|}{ Experiment 1 } & \multicolumn{2}{c|}{ Experiment 2 } & \multicolumn{2}{c|}{ Experiment 3 } & \multirow{2}{*}{ task } \\
\cline { 2 - 7 } & charge & ingot & charge & ingot & charge & ingot & \\
\hline $\mathrm{Al}$ & 9,2 & 12,45 & 12,5 & 6,94 & 8,2 & 6,9 & $7-8$ \\
\hline $\mathrm{Zr}$ & 4 & 3,53 & 3,5 & 2,5 & 4 & 3,49 & 34 \\
\hline $\mathrm{Si}$ & 1,6 & 1,36 & 1,33 & 1,17 & 1,2 & 1 & $0,9-1,1$ \\
\hline $\mathrm{Nb}$ & 0,82 & 0,56 & 0,9 & 0,98 & 1,18 & 0,7 & $0,8-1,2$ \\
\hline $\mathrm{Mo}$ & 0,82 & 0,56 & 0,9 & 0,8 & 1,15 & 0,79 & $0,7-1$ \\
\hline $\mathrm{Sn}$ & 2 & 1,55 & 2,3 & 1,9 & 2,5 & 1,9 & $2-3$ \\
\hline Weight, $\mathrm{kg}$ & 7,25 & 5,65 & 5,712 & 5,7 & 6,93 & 6,9 & $5,5-7,5$ \\
\hline
\end{tabular}

The first experiment was performed according to the regime, which performed a gradual increase of electron beam heating power up to 45-60 kW with further activation of electromagnetic stirring. The melting was carried out until the temperature of the cooling water, which cools crucible, stopped at the required level, which corresponded to the heating power of $80-90 \mathrm{~kW}$. After this, a charge consisting of aluminum, silicon, and tin was fed to the electron beam focus area via the manipulator. The injection lasted 1 minute and the melting after the injection lasted the same.

Analyzing the data in the table, we can conclude that the addition of colder metal into melt significantly lowered the total temperature of the liquid metal bath and led to metal freezing on the walls of the skull. Thus, the aluminum dissolved only in less than the required volume of melt remaining in the liquid state. Despite the rather high melting power, the melting time after the injection of the fusible components was not enough.

During the second experiment, the as-cast ingot from previous experiment was used. Addition charging with molybdenum, niobium and tin have been provided via deposition inside the crucible. The melting was carried out in a similar mode, but the maximum power of electron beam heating was $75-80 \mathrm{~kW}$. This time, the point of the melt downpour was the cooling water temperature, value of which exceeded by $0,5^{\circ} \mathrm{C}$, compared to previous experimental regime. The purpose of this solution was to blur the volumes of metal, frozen in the previous experiment and thus to fuse addition molybdenum, niobium and tin from 
the bottom of a skull. As can be seen from the chemical composition data in the table, the accuracy of the results was quite high. The biggest discrepancy was that of zirconium content. It can be explained due to the fact that zirconium has a much lower magnetic permeability than titanium and a substantially higher density. So, over time, some of it may accumulate on the walls of the skull and settle at the bottom without distribution if the volume of the liquid metal bath is maintained at a constant level during the last period of melting.

The conclusions drawn from the previous two melts were used for the third experiment. The as-cast ingot, obtained in the second experiment, was remelted with adding Mo, $\mathrm{Nb}$ and $\mathrm{Zr}$ inside the crucible as the charge. Small amounts of $\mathrm{Si}, \mathrm{Sn}$ and Al were added in small amount from the manipulator at the end of the melting process. The liquid melt preparation mode was similar to the second test mode, but its duration was $30 \%$ longer. The duration increase was pursued by the goal of increasing the volume of the melt and obtaining the casting of more liquid metal volume. The temperature of the cooling crucible was $15 \%$ higher, than during the first test and $10 \%$ higher than the second. As a result, a obtained sample was had the best requirements.

According to the results of the experiments, the following features of the complexalloyed $\mathrm{Ti}-\mathrm{Al}-\mathrm{Si}-\mathrm{Zr}-\mathrm{Mo}-\mathrm{Nb}-\mathrm{Sn}$ composition smelting conditions under EBCT conditions were determined:

EBCM is a promising method for producing as-cast parts and semi-finished products from complex titanium alloys with high amount of aluminum and refractory metals.

It's clarified, that $\mathrm{Zr}$ and other comparably heavy elements are able to sediment on the bottom of skull without increasing of liquid metal volume during the melting process.

To obtain an accurate chemical composition of as-cast part it should be considered the loss of $\mathrm{Zr}, \mathrm{Sn}, \mathrm{Mo}$ and $\mathrm{Nb}$ at the level about 25-32 \%.

Addition of $\mathrm{Al}$ and $\mathrm{Si}$ is better to provide by their injection from a liquid state, including moderate considering of their loss during further melting process.

\section{References}

1. lliyin, A. A., Kolatchev, B. A., Polkin, I. S. (2009) Titanium alloys: Composition, structure, properties. Handbook. Moscow: VILS-MATI [in Russian].

2. Kolatchev, B. A., lelagin, V. I., lelagin, V. A. (2005) Metal science and heat treatment of non-ferrous metals and alloys. Moscow: MISiS [in Russian].

3. Firstov, S. O., Kulak, L. D., Kuzmenko, M. M., Shevchenko, O. M. (2019) Alloys of the Ti-Al-Zr-Si System Intended for Operation at High Temperatures. Materials Science. Vol. 54, Issue 6, pp. 783-788.

4. Xuesong Zhang, Yongjun Chen, Junling Hu (February, 2018) Recent advances in the development of aerospace materials. Progress in Aerospace Sciences. Vol. 97, pp. 22-34.

5. Antunes, R., Salvador, C. (2018) Materials Selection of Optimized Titanium Alloys for Aircraft Applications. Materials Research. Vol. 21, no. 2, pp. 1-9.

6. Kablov, Ye. N., Lukin, V. I. (2008) Intermetallides of titanium and nickel for products of new technology. Welding and related technologies, 11. pp. 76-82 [in Russian].

7. Ivanov, V. I., Yasinskyi, K. K. (1996) Efficiency of using heat-resistant alloys based on Ti3Al and TiAl intermetallics for work at temperatures of $600-800^{\circ} \mathrm{C}$ in aerospace engineering. Light alloys technology, no. 3, pp. 63-68 [in Russian].

8. Cavaliere P., Mehtedi M. El., Evangelista E., Kuzmenko N., Vasylyev O. (2006) Hot forming behaviour of $\mathrm{Ti}-\mathrm{Al}-\mathrm{Zr}$-Si "in situ" metal matrix composite by means of hot torsion tests. Composites Part A: Applied Science and Manufacturing. Vol. 37, Issue 10. - P. 1514-1520.

9. Ivasyshyn, A. D., Ostash, O. P., Kuz'menko, M. M. (2008) Influence of the structure on the hightemperature cyclic crack resistance of Ti-8Al-1.4Si-2.2Zr alloy. Materials Science. Vol. 44, no. 3, pp. 360-367.

10. Kuz'menko, M. M. (2008) Structure and mechanical properties of cast alloys of the Ti-Si system. Materials Science. Vol. 44, no. 1, pp. 49-53.

11. Microstructure and properties of materials. Vol. 2. / Ed. by James, C. M. Li. London.: World Scientific publishing Co. Pte. Ltd, 2000, 423 p.

12. Titanium: a technical guide, 2 nd edition / Ed. by Metthew J., Donachie Jr. Winchester, USA: ASM International, 2000, $380 \mathrm{p}$. 
13. Materials properties handbook. Titanium alloys / Ed. by R. Boyer, G. Welsch, E. W. Collings. Winchester, USA: ASM International, 1994, $1173 \mathrm{p}$.

14. Zhang, W. J., Song, X. Y., Hui, Songxiao, Ye W. J., Wang Y. L., Wang, W. Q. (2014) Tensile behavior at $700^{\circ} \mathrm{C}$ in Ti-Al-Sn-Zr-Mo-Nb-W-Si alloy with a bi-modal microstructure. Materials Science and Engineering: A, no. 595, pp. 159-164.

15. Diao, Y., Song, X., Zhang, W., Zhao M., Ye W., Hui, S. (2018) Microstructure and Mechanical Properties of a Ti-Al-Sn-Zr-Mo-Nb-W-Si High-Temperature Titanium Alloy: Proceedings of Chinese Materials Conference, pp. 6-9.

16. Electron beam melting in foundry / Ed. by S. V. Ladokhin (2007) Kyiv: «Stal» [in Russian]

17. Kovalchuk, D. V., Kondratiy, N. P. (2008) Electron beam remelting of titanium - problems and development prospects. Ti-2008 in the CIS. Proceedings of the international conference, Russia, St. Petersburg, pp. 25-32. [in Russian]

18. Levitskyi, N. I., et al. (2012) Obtaining complex alloyed titanium alloys by electron beam skull melting. Metal and casting of Ukraine, no. 4, pp. 6-9. [in Russian]

19. Voron, M. M., Drozd, Ye A., Lapshuk, T. V. (2016). Features of the structural and phase state of cast titanium alloys Grade5 and Timet-10-2-3 obtained by electron beam smelting. Casting processes, no. 3. pp. 63-68. [in Russian].

Recieved 04.05.2020

\section{Список літератури}

1. Ильин А. А., Колачев Б. А., Полькин И. С. Титановые сплавы: Состав, структура, свойства. Справочник. Москва: ВИЛС-МАТИ, 2009. 520 с.

2. Колачев Б. А., Елагин В. И., Ливанов В. А. Металловедение и термическая обработка цветных металлов и сплавов. Москва: МИСиС, 2005. 432 с.

3. Firstov S. O., Kulak L. D., Kuzmenko M. M., Shevchenko O. M. Alloys of the Ti-Al-Zr-Si System Intended for Operation at High Temperatures. Materials Science, 2019, V. 54, Issue 6, pp. 783-788.

4. Xuesong Zhang, Yongjun Chen, Junling Hu. Recent advances in the development of aerospace materials. Progress in Aerospace Sciences, Volume 97, February 2018, pp. 22-34.

5. Antunes R., Salvador C. Materials Selection of Optimized Titanium Alloys for Aircraft Applications. Materials Research, 2018, vol. 21, № 2. pp. 1-9.

6. Каблов Е. Н., Лукин В. И. Интерметаллиды титана и никеля для изделий новой техники. Сварка и родственные технологии, 2008, № 11, С. 76-82.

7. Иванов В. И., Ясинский К. К. Эфективность применения жаропрочных сплавов на основе интерметаллидов Ti3Al и TiAl для работы при температурах $600-800^{\circ} \mathrm{C}$ в авиакосмической технике. Технология легких сплавов, 1996, № 3, С. 63-68.

8. Cavaliere P., Mehtedi M. El., Evangelista E., Kuzmenko N., Vasylyev O. Hot forming behaviour of Ti-Al-Zr-Si "in situ" metal matrix composite by means of hot torsion tests. Composites Part A: Applied Science and Manufacturing, 2006, Vol. 37, Issue 10, pp. 1514-1520.

9. Ivasyshyn A.D., Ostash O.P., Kuz'menko M.M. Influence of the structure on the high-temperature cyclic crack resistance of Ti-8Al-1.4Si-2.2Zr alloy // Materials Science, 2008, V. 44, no 3, pp. 360-367.

10. Kuz'menko M. M. Structure and mechanical properties of cast alloys of the Ti-Si system. Materials Science, 2008, V. 44, no 1, pp. 49-53.

11. Microstructure and properties of materials. Vol. 2. / Ed. by James C. M. Li. London: World Scientific publishing Co. Pte. Ltd, 2000. 423 p.

12. Titanium: a technical guide, 2nd edition / Ed. by Metthew J., Donachie Jr. Winchester, USA: ASM International, 2000. $380 \mathrm{p}$.

13. Materials properties handbook. Titanium alloys / Ed. by R. Boyer, G. Welsch, E. W. Collings. Winchester, USA: ASM International, 1994. 1173 p.

14. Zhang, W. J., Song, X. Y.,Hui, Songxiao, Ye W. J.,Wang Y. L., Wang, W. Q. Tensile behavior at $700^{\circ} \mathrm{C}$ in Ti-Al-Sn-Zr-Mo-Nb-W-Si alloy with a bi-modal microstructure. Materials Science and Engineering: A. 2014, no 595, pp. 159-164.

15. Diao, Y., Song, X., Zhang, W., Zhao M., Ye W., Hui, S. Microstructure and Mechanical Properties of a Ti-Al-Sn-Zr-Mo-Nb-W-Si High-Temperature Titanium Alloy: Proceedings of Chinese Materials Conference 2018, pp. 6-9.

16. Электронно-лучевая плавка в литейном производстве / Под ред. С. В. Ладохина. Киев: Изд-во «Сталь». 2007. 626 с.

17. Ковальчук Д. В., Кондратий Н. П. Электронно-лучевой переплав титана - проблемы и перс- 
пективы развития. Ті-2008 в СНГ. Сборник трудов международной конференции. Россия, г. Санкт-Петербург, 18-21 мая 2008. С. 25-32.

18. Левицкий Н. И., Матвиец Е. А., Лапшук Т. В. и др. Получение сложнолегированныхтитановых сплавов методом электронно-лучевой гарнисажной плавки. Металл и литье Украины. 2012. № 4. С. 6-9.

19. Ворон М. М., Дрозд Е. А., Лапшук Т. В. Особенности структурно-фазового состояния литых титановых сплавов Grade5 и Timet-10-2-3 электронно-лучевой выплавки. Процессы литья. 2016. № 3. С. 63-68.

С. В. Ладохін, д-р техн. наук, гол. наук. співр.

М. М. Ворон, канд. техн. наук, ст. наук. співр., e-mail: mihail.voron@gmail.com

Є. О. Дрозд, мол. наук. співр.

Є. О. Матвієць, гол. технолог

*Л. Д. Кулак, канд. техн. наук., ст. наук. співр.

*М. М. Кузьменко, канд. техн. наук, ст. наук. співр.

Фізико-технологічний інститут металів та сплавів НАН України

* Інститут проблем матеріалознавства ім. І. М. Францевича НАН України

\title{
ОСОБЛИВОСТІ ОДЕРЖАННЯ ТИТАНОВИХ СПЛАВІВ СИСТЕМИ Ti-Al-Si-Zr-Mo-Nb-Sn В УМOBAX ЕЛЕКТРОННО-ПРОМЕНЕВОЇ ЛИВАРНОЇ ТЕХНОЛОГІї
}

\begin{abstract}
Робота присвячена питанню одержання жароміцного складнолегованого титанового сплаву системи Ti-Al-Si-Zr додатково легованих Mo, Nb та Sn в умовах електронно-променевої ливарної технології. На основі сучасних тенденцій розробки жароміцних титанових сплавів проведено аналіз розробок композицій, які працюють при температурах $600^{\circ} \mathrm{C}$ та потенційно здатні працювати при температурах до $700^{\circ} \mathrm{C}$. Зроблено висновки, що відомі комерційні сплави, в яких реалізовано механізм твердо розчинного зміцнення, а також сплави на основі інтерметалідів мають ряд недоліків та не в повній мірі відповідають сучасним вимогам, які висуваються до даного класу матеріалів. Показано, що розробка і створення титанових сплавів, які можуть поєднувати в собі механізми твердорозчинного та силіцидного зміцнення $\epsilon$ найбільш перспективним рішенням для значного підвищення їх високотемпературних характеристик. Одним із прикладів такої групи сплавів $є$ композиція Ti-7Al-1Si-4Zr-1Mo$1 \mathrm{Nb}-1 \mathrm{Sn}$, розроблена в IПМ НАН України. Такий сплав $є$ не надто вартісним та дещо легшим за існуючі аналоги. Виробництво готових виробів та напівфабрикатів з таких сплавів зазвичай здійснюється методами лиття, або за допомогою металургійної технології електроннопроменевого переплаву. 3 огляду на експериментальний характер сплаву виникає потреба в дослідженні технологічних особливостей виплавки такого матеріалу, визначенні особливостей поведінки компонентів в процесі приготування розплаву та одержанні якісних заготовок для подальшої термомеханічної обробки та досліджень. Для вирішення цих задач найбільш доцільним є застосування електронно-променевої ливарної технології. Вході експериментів з виплавки експериментального сплаву визначено технологічні особливості приготування розплаву необхідного хімічного складу, серед яких основними були - процедура введення алюмінію та замішування елементів з високою густиною.
\end{abstract}

Ключові слова: жароміцні титанові сплави, система Ti-Al-Si-Zr-Mo-Nb-Sn, електроннопроменева ливарна технологія, лиття титану та його сплавів. 